\title{
Sickle-cell Haemoglobin O Disease in a Sudanese Family
}

\author{
S. A. IBRAHIM,* D.K.S.M., PH.D.; DAOUD MUSTAFA, $\dagger$ D.K.S.M., F.R.C.P.
}

Brit. med. F., 1967, 3, 715-717

Besides sickle-cell anaemia, the finding of $\mathrm{Hb} S$ with other $\beta$-chain variants of adult haemoglobin was first demonstrated by Itano and Neel (1950) in the well-known discovery of sicklecell $\mathrm{Hb} \mathrm{C}$ disease. Since then $\mathrm{Hb} \mathrm{S}$ has been observed with $\mathrm{Hb} \mathrm{D}, \mathrm{E}, \mathrm{G}, \mathrm{J}$, and $\mathrm{K}$ (Itano, 1951 ; Aksoy and Lehmann, 1957 ; Schwartz and Spaet, 1955 ; Went and MacIver, 1959 ; O'Gorman et al., 1963). In such circumstances there is a sickle-cell disease which, while of varying severity, is milder than the homozygous sickle-cell anaemia.

$\mathrm{Hb} S$ was first observed with $\mathrm{Hb} \mathrm{O}$ in two children of an Arab family who were reported to be suffering from a sicklecell $\mathrm{Hb} \mathrm{O}$ trait condition. In those cases some $\mathrm{Hb} \mathrm{A}$ was also found in addition to $\mathrm{Hb} S$ and $\mathrm{O}$ (Ramot et al., 1960), and it was subsequently concluded that there must have been a previous blood transfusion (Baglioni and Lehmann, 1962). The clinical picture of sickle-cell $\mathrm{Hb} \mathrm{O}$ disease has not yet been reported. The present report describes two cases which occurred in a Sudanese family.

\section{Case 1}

A Sudanese man aged 27 coming from the village of Abu Haraz, Gezira, was admitted into Khartoum Hospital on 1 September 1966 complaining of joint pains and malaise for one month and fever for seven days. Since early childhood he had suffered from similar attacks with occasional episodes of jaundice, which were often precipitated by exertion. During infancy he had bouts of screaming, and was once taken to a native healer, who manipulated the patient's upper limbs. It was thought that as a result of such manipulations he developed severe tenderness and swelling of the left shoulder. The swelling was later incised and pus was drained. The patient had had the last attack of joint pains about a month previously when he was admitted to a district hospital, and it was while there that severe pain developed, with swelling of the right shoulder. The condition was diagnosed as rheumatoid arthritis and he was given salicylates and corticosteroids without benefit. The pain and swelling in the right shoulder persisted till his admission into Khartoum Hospital. Four months previously he had been found to have intestinal schistosomiasis and was treated with stibophen (Fouadin).

On admission he was ill-looking, in pain, wasted, and anaemic but not jaundiced. He had a large skull and was running a temperature of $103^{\circ} \mathrm{F} .\left(39.4^{\circ}\right.$ C.). Heart, lungs, and abdomen were normal ; liver and spleen were not palpable. He had brisk tendon reflexes, but otherwise the nervous system was normal. The fundus oculi showed slight engorgement of the retinal veins and arterio-

TABLB I.-Haematological Findings in Two Patients Suffering from Sickle-cell $\mathrm{Hb} \cdot \mathrm{O}$ Disease

\begin{tabular}{|c|c|c|c|c|c|c|c|c|}
\hline $\begin{array}{c}\text { Case } \\
\text { No. }\end{array}$ & $\begin{array}{c}\text { Age } \\
\text { in } \\
\text { Years }\end{array}$ & $\begin{array}{c}\text { Sickling } \\
\text { Test }\end{array}$ & $\begin{array}{c}\text { Adult } \\
\text { Haemo- } \\
\text { globins }\end{array}$ & $\begin{array}{c}\mathrm{Hb} \text { F } \\
(\%)\end{array}$ & $\begin{array}{c}\text { Haemo- } \\
\text { globin } \\
(\mathrm{g} .1 \\
100 \mathrm{ml} .)\end{array}$ & $\begin{array}{l}\text { P.C.V. } \\
\text { (\%) }\end{array}$ & $\underset{(\%)}{\text { M.C.H.C. }}$ & $\begin{array}{c}\text { Reticu- } \\
\text { locytes } \\
(\%)\end{array}$ \\
\hline$\frac{1}{2}$ & $\begin{array}{l}27 \\
15\end{array}$ & $\begin{array}{l}+ \\
+\end{array}$ & $\begin{array}{l}s+0 \\
s+0\end{array}$ & $\begin{array}{l}5 \cdot 5 \\
4 \cdot 5\end{array}$ & $9_{9}^{8 \cdot 5}$ & $\begin{array}{l}28 \\
29\end{array}$ & $\begin{array}{l}34 \\
31\end{array}$ & $\begin{array}{l}0 \cdot 8 \\
18\end{array}$ \\
\hline
\end{tabular}

venous nipping. The right shoulder was swollen, hot, and tender, with induration of the overlying deltoid and adjacent pectoralis major. Movements were restricted on account of pain. The left arm was smaller and $8 \mathrm{~cm}$. shorter than the right.

Investigations.-The haematological findings are given in Table I. A peripheral blood film showed many target cells, a few sickle cells,

\footnotetext{
- Department of Biochemistry, Faeulty of Medicine, University of

t Department of Medicine, Faculty of Medicine, University of Khartoum.
}

and some normoblasts. The erythrocytes showed anisocytosis and poikilocytosis. No malaria parasites were seen. Total W.B.C. $6,400 / \mathrm{cu}$. mm. (polymorphs $61 \%$, lymphocytes $35 \%$, eosinophils $2 \%$, and monocytes $2 \%$ ). Bone marrow was predominantly normo-

TABLE II.-Blood Chemistry in Two Patients Suffering from SO Disease

\begin{tabular}{|c|c|c|c|c|c|c|c|}
\hline \multirow{2}{*}{$\begin{array}{l}\text { Case } \\
\text { No. }\end{array}$} & \multirow{2}{*}{$\begin{array}{c}\text { Serum } \\
\text { Bili- } \\
\text { rubin } \\
\text { (mg.l } \\
100 \mathrm{ml} .)\end{array}$} & \multirow{2}{*}{$\begin{array}{l}\text { Alkaline } \\
\text { Phos- } \\
\text { phatase } \\
\text { (K.A. } \\
\text { Units) }\end{array}$} & \multirow{2}{*}{$\begin{array}{l}\text { Thymol } \\
\text { Turbidity }\end{array}$} & \multicolumn{4}{|c|}{$\begin{array}{c}\text { Plasma Proteins } \\
(\mathbf{g} . / 100 \mathrm{ml} .)\end{array}$} \\
\hline & & & & Total & $\begin{array}{c}\text { Albu- } \\
\min \end{array}$ & $\begin{array}{l}\text { Glo- } \\
\text { bulin }\end{array}$ & $\begin{array}{c}\gamma \text {-Glo- } \\
\text { bulin }\end{array}$ \\
\hline$\frac{1}{2}$ & $\begin{array}{l}0.8 \\
2.2\end{array}$ & $\begin{array}{l}18 \\
21\end{array}$ & $\begin{array}{l}1 \\
8\end{array}$ & $\begin{array}{l}7.6 \\
7.8\end{array}$ & $\begin{array}{l}2.4 \\
1.9\end{array}$ & $\begin{array}{l}5.2 \\
5.9\end{array}$ & $\begin{array}{l}2 \cdot 9 \\
3 \cdot 2\end{array}$ \\
\hline
\end{tabular}
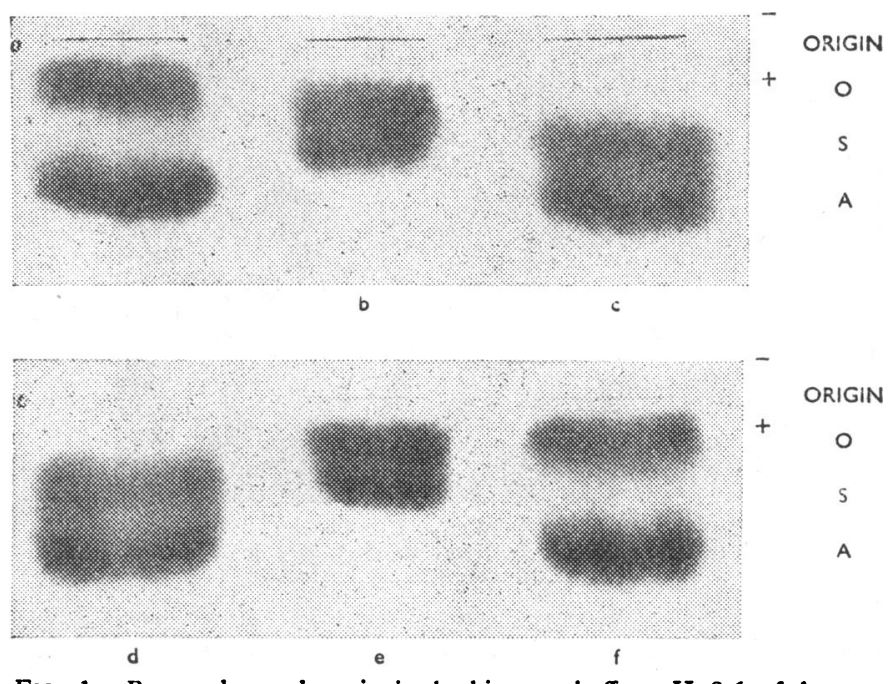

Fig. 1.-Paper electrophoresis in barbiturate buffer $p H 8.6$ of haemoglobins from two patients with SO disease and their parents. a and $f$ Mother's haemoglobin, showing $\mathrm{Hb} \mathrm{A}+\mathrm{O}$. b: Haemoglobin of Case 1, showing $\mathrm{Hb} \mathrm{S}+\mathrm{O}$. $c$ and $\mathrm{d}$ : Father's haemoglobin, showing $\mathrm{Hb} \mathrm{A}+\mathrm{S}$. e : Haemoglobin of Case 2, showing $\mathrm{Hb} \mathrm{S}+\mathrm{O}$.

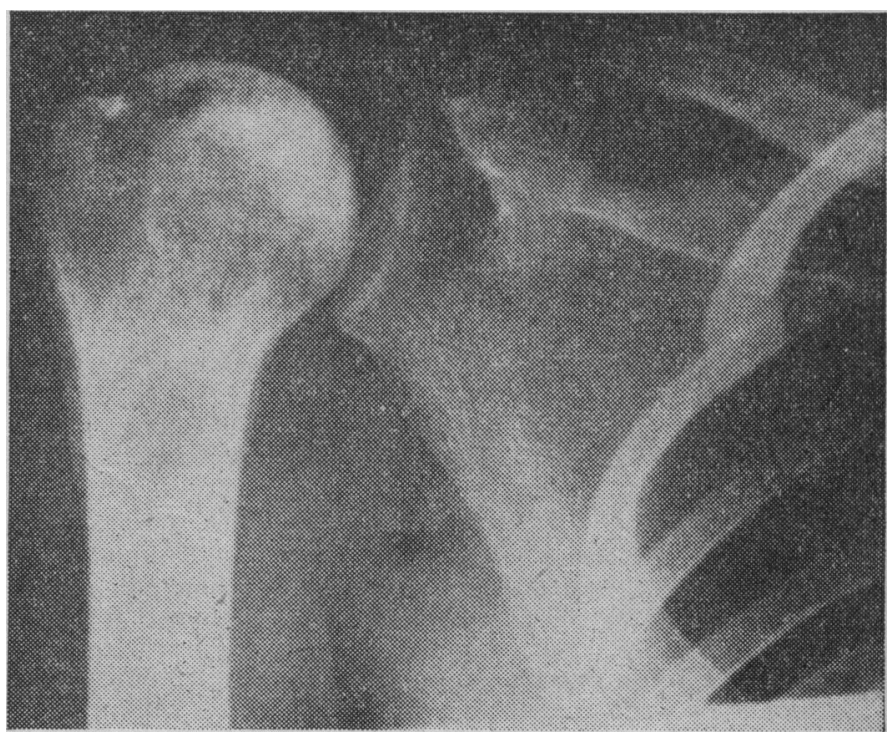

Fig. 2.-Case 1. $X$-ray film of right shoulder, showing osteoporosis of the hend of the right humerus, thinning of cortex, and periosteal reaction in the humeral neck. 
blastic with a fair number of megaloblasts and an increase of plasma cells. The blood chemistry is shown in Table II. Urine contained an excessive amount of urobilinogen, a trace of protein, but no R.B.C.s or bilirubin. Stools were repeatedly negative for schistosome ova. Haemoglobin electrophoresis showed $\mathrm{Hb} \mathrm{S}+\mathrm{O}$ (Fig. 1). This finding was confirmed by Dr. H. Lehmann at the M.R.C. Abnormal Haemoglobin Research Unit, Cambridge. Hb F constituted $5.5 \%$ of total haemoglobin. Electrophoresis of serum, using barbitone buffer, revealed a marked increase in the $\gamma$-globulin fraction. $X$-ray examination showed osteoporosis of the head of the right humerus, thinning of the cortex, and periosteal reaction in the humeral neck (Fig. 2). The skull was osteoporotic with opacities, and had a hair-on-end appearance. The left humerus was small, short, and had a very small remnant of a head (Fig. 3).

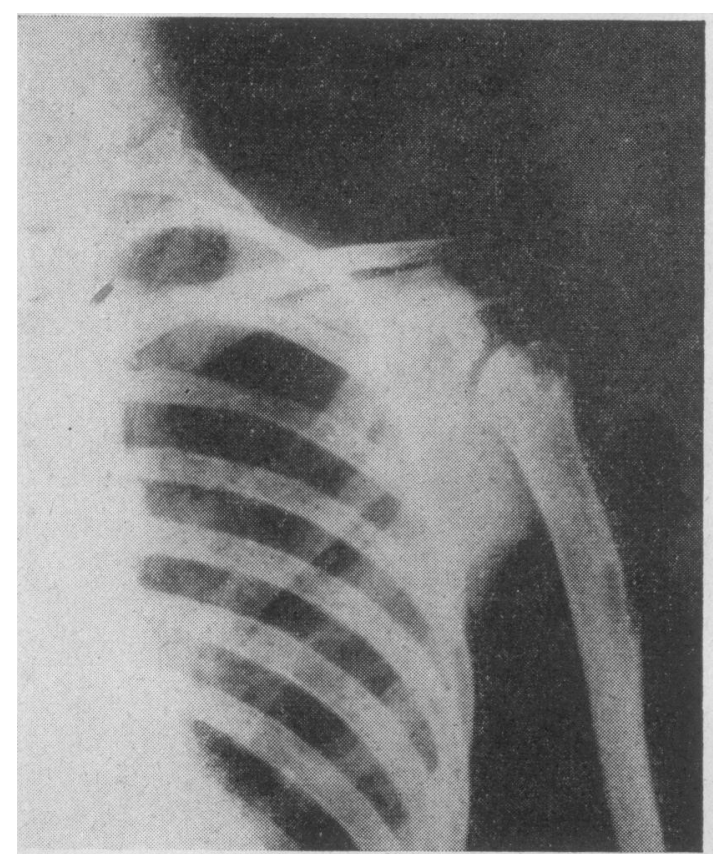

FIG. 3.- Case 1. $X$-ray film of left shoulder, showing a small remnant of left humeral head, thinning of cortex, and periosteal reaction in the shaft.

He ran a temperature of up to $102^{\circ} \mathrm{F} .\left(38.9^{\circ} \mathrm{C}\right.$.) for three weeks. The swelling in the right shoulder improved very slowly. On 25 October he complained of severe pain in the left loin and had microscopic haematuria, which cleared up in about a week. On 30 October a painful swelling appeared in the middle of his left femur which subsided in about a week. On 1 December the right shoulder swelling and pain got much worse. He was put on folic acid tablets, and this converted the marrow to normoblastic and resulted in haematological improvement.

\section{Case 2}

A Sudanese girl aged 15, sister of Case 1, was admitted to hospital on 1 October 1966, having had jaundice for two months, fever and cough for one month, and a painful swelling of the left shoulder for 10 days.

Since early childhood she had suffered from attacks of joint pains sometimes associated with swellings. At the age of 3 years she had a severe attack of measles accompanied by a painful swelling of both hands, including the fiingers. Since then some fingers were noted to have become shorter. At the age of 6 she had jaundice, which lasted for one month.

On admission she had a temperature of $100^{\circ} \mathrm{F}$. $\left(37.8^{\circ} \mathrm{C}\right.$.) and was looking very ill, wasted, anaemic, and mildly jaundiced. Pulse was collapsing; B.P. 100/60; apex beat was in fourth space at the midclavicular line. No murmurs were heard. There were signs of right lower lobar pneumonia, and tender bony swellings were present on the seventh and eighth right ribs and on the sixth, eighth, and ninth left ribs at the midaxillary line. Liver and spleen were not palpable. Besides brisk tendon reflexes, the nervous system was normal. There was a moderately swollen left shoulder, which was hot and tender. The right middle finger was short and the proximal interphalangeal joint of the left index was ankylosed.

Investigations.-The haematological findings were as follows. A peripheral blood smear with many target cells, a few sickle cells, and erythrocytes showing anisocytosis and poikilocytosis. No malaria parasites were seen. Total W.B.C. 10,300/cu. mm. (polymorphs $69 \%$, lymphocytes $24 \%$, monocytes $5 \%$ and metamyelocytes $2 \%$ ). The bone marrow was hyperactive, predominantly normoblastic, with a fair number of megaloblasts and an increase in plasma cells. E.S.R. $7 \mathrm{~mm}$. in the first hour (Westergren). Serum calcium was $9.9 \mathrm{mg} . / 100 \mathrm{ml}$. and phosphorus $3.8 \mathrm{mg}$./ $100 \mathrm{ml}$. The rest of the blood chemistry is shown in Table II. The urine contained a fair number of erythrocytes, urobilinogen in excess, but no bilirubin. Stools were normal. Electrophoresis of the haemoglobin revealed $\mathrm{Hb} \mathrm{S}+\mathrm{O}$, a finding that was confirmed by Dr. H. Lehmann. Hb F constituted $4.5 \%$ of the total haemoglobin. Electrophoresis of serum showed a considerable increase in the $\gamma$-globulin fraction. $X$-ray examination of the chest showed right lower zone opacity and small areas of bone destruction in the right eighth and ninth ribs and to a less extent in the left sixth and eighth ribs at the sites corresponding to the tender swellings seen externally. An $x$-ray film of both hands (Fig. 4) showed that with the exception of the thumb the fingers of the left hand were all shorter than normal owing to reduction of the proximal and middle phalanges. The proximal phalanx of the right middle finger was also short. The ends of the affected phalanges showed osteoporosis, with cupping at the metacarpophalangeal and interphalangeal joints and reduction of joint spaces.

The patient maintained a low-grade fever for three weeks. The pneumonia and rib swellings subsided gradually. On 15 October she developed a painful swelling over the right radius; this subsided in a few days. On 8 November the old rib swellings subsided but two new non-tender swellings of the right eighth and ninth ribs appeared in the scapular line. On 30 November the left shoulder swelling and pain became worse. She was put on folic acid, and this converted the marrow to normoblastic with haematological improvement.

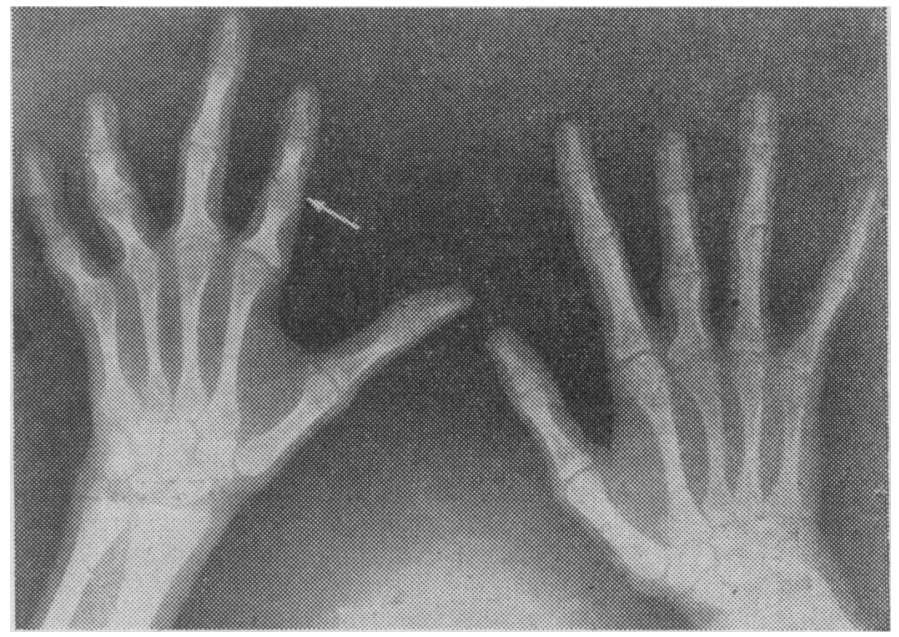

FIG. 4.-Case 2. $X$-ray film of both hands, showing shortening of the proximal and middle phalanges, osteoporosis, and cupping at the joints of the affected fingers. The proximal interphalangeal joint of the left index is ankylosed.

\section{Family History}

The parents are distant cousins; both are alive and well. They have eight more siblings-five daughters and three sons-who are reported to be well. One child died four days after birth.

Electrophoresis of haemoglobin showed that the father has $\mathrm{Hb}$ $\mathrm{A}+\mathrm{S}$ while the mother has $\mathrm{Hb} \mathrm{A}+\mathrm{O}$ (see Fig. 1). The rest of the family have not yet been examined.

\section{Discussion}

The incidence of $\mathrm{Hb} S$ and $\mathrm{O}$ Arab in Northern Sudanese has been reported as 2 and $0.1 \%$ respectively (Vella et al., 1966). 
Examination of the peptides arising from tryptic digestion of the abnormal haemoglobin has shown that haemoglobin $O$ Arab harbours the chemical abnormality in the $\beta$-polypeptide chains of the molecule (Baglioni and Lehmann, 1962). It has also been shown that $\mathrm{Hb} S$ differs from $\mathrm{Hb} \mathrm{A}$ in the amino-acid composition of the $\beta$-polypeptide chains (Ingram, 1959). Since adult haemoglobins are genetically determined by allelomorphic genes inherited in a Mendelian fashion, then the inheritance of the genes for $\mathrm{Hb} S$ and $\mathrm{O}$ by an individual will result in the formation of only $\mathrm{Hb} \mathrm{S}+\mathrm{O}$ by that individual. $\mathrm{No} \mathrm{Hb}$ A will therefore be formed, since the genes for $\mathrm{Hb} S$ and $\mathrm{O}$ both produce haemoglobins which are abnormal in the $\beta$-chains.

The clinical picture of sickle-cell $\mathrm{Hb} \mathrm{O}$ disease has hitherto not been described. Both patients whose cases are reported here are Northern Sudanese of Arab ancestry in whom the onset of symptoms of the disease began early in life. The bony lesion of the left shoulder in Case 1 and of both hands in Case 2 are probably manifestations that had taken place in infancy and early childhood respectively. The onset of symptoms in sickle-cell disease is generally later than in sicklecell anaemia, though it has been reported that in about $80 \%$ of the cases of SC disease the symptoms began in the first decade of life (Hook and Cooper, 1958).

The most prominent clinical features in these two cases of SO disease are the joint pains and bony lesions involving humeri, ribs, skull, hands, femur, and radius, and of particular prominence is the marked affliction of the head of the humerus. Aseptic necroses of the femoral and humeral epiphyses are very common in SC disease (Smith and Conley, 1954; Hook and Cooper, 1958 ; Ranney, 1958). Burchmore et al. (1962) suggested that arterial occlusion rather than capillary obstruction may be the main factor in the production of avascular necroses, multiple infarcts, and painful swellings seen in SC disease. Indeed, these authors provided unequivocal evidence of arterial occlusion in the case they reported.

Another prominent feature in our cases is the marked decrease of plasma albumin along with the considerable increase in $\gamma$-globulin. The common diseases which cause such a disturbance of plasma proteins in the Sudan are leishmaniasis, hepatosplenic schistosomiasis, chronic malaria, and hepatic cirrhosis. These two patients were not suffering from leishmaniasis and there was no evidence of chronic malaria. Though Case 1 gave a history of intestinal schistosomiasis for which he received treatment there was no clinical evidence of hepatosplenic involvement. Liver disease and disturbed liver function have been described in cases of sickle-cell anaemia. Thus decreased plasma albumin and increased $\gamma$-globulin were reported by Fenichel et al. (1950). Histological evidence of liver disease, together with disturbance in plasma proteins and liver function tests, was also given by Green et al. (1953). In the case of SC disease described by Burchmore et al. (1962) a considerable increase in the $\gamma$-globulin was also reported. It would seem probable that the disturbances in plasma proteins seen in our patients were due to hepatic disease. In both cases there was an increase in plasma cells in the bone marrow. Patients with liver disease who have very high serum globulin show plasmocytosis of the bone marrow (Sherlock, 1963).

In neither of our cases was there a palpable spleen. Splenomegaly occurs in the majority of cases of SC disease, in contrast to sickle-cell anaemia, in which a palpable spleen is detected in only a small proportion of cases (Wintrobe, 1961). However, Edington (1957) reported that in some cases of SC disease the spleen may be fibrosed and hence cannot be felt.
Though in both cases the anaemia has been severe, it is fairly well tolerated. Both had megaloblastic erythropoiesis. Haemolytic anaemia as a factor in the development of megaloblastic erythropoiesis has been demonstrated in the specific case of sickle-cell anaemia by Jonsson et al. (1959) and by WatsonWilliams (1962). Megaloblastic anaemia complicating SC disease has been reported by Fullerton and Watson-Williams (1962), and the megaloblastosis has been attributed to excessive folic acid requirements.

It is of interest to note that one of our patients (Case 1) developed severe left loin pain which was associated with microscopic haematuria otherwise not observed in previous urine tests. Haematuria occurs in sickle-cell anaemia and in sickle-cell trait (Wintrobe, 1961). Massive haematuria that is probably the result of renal arterial occlusion (Burchmore et al., 1962) often occurs in SC disease (Smith and Conley, 1954, 1958).

\section{Summary}

Two cases of a hitherto undescribed condition of sickle-cell $\mathrm{Hb} \mathrm{O}$ disease are reported in detail and the relevant literature is reviewed. The prominent features of this condition (SO disease) are joint pains, bony lesions, anaemia, and marked disturbances of the plasma proteins. The occurrence of megaloblastic anaemia is also reported. Like other sickle-cell diseases, SO disease is relatively mild. The clinical picture bears some resemblance to that of SC disease.

We are grateful to Dr. H. Lehmann, Director, M.R.C. Abnormal Haemoglobin Research Unit, Cambridge, for confirming the finding of the abnormal haemoglobins and for valuable discussions while he was in Khartoum; to Mr. T. R. Davis, Faculty of Pharmacy, Khartoum, for photographing the electrophoretograms ; to Professor K. R. Adam, of the Biochemistry Department, for advice ; and to Research Assistant Dr. El Daw Mokhtar for help.

\section{REFERENCES}

Aksoy, M., and Lehmann, H. (1957). Nature (Lond.), 179, 1248.

Baglioni, C., and Lehmann, H. (1962). Ibid., 196, 229.

Burchmore, J. W., Buckle, R. M., Lehmann, H., and Jenkins, W. J. (1962). Lancet, 2, 1008.

Edington, G. M. (1957). F. clin. Path., 10, 182

Fenichel, R. L., Watson, J., and Eirich, F. (1950). 7. clin. Invest., 29,

Fullerton, W. T., and Watson-Williams, E. J. (1962). F. Obstet. Gynaec. Brit. Cwlth, 69, 729 .

Green, T. W., Conley, C. L., and Berthrong, M. (1953). Bull. Fohns Hopk. Hosp., 92, 99.

Hook, E. W., and Cooper, G. R. (1958). Sth. med. F. (Bgham, Ala.), 51, 610

Ingram, V. M. (1959). Nature (Lond.), 183, 1795.

Itano, H. A. (1951). Proc. nat. Acad. Sci. (W ash.), 37, 775.

- and Neel, J. V. (1950). Ibid., 36, 613.

Jonsson, U., Roath, O. S., and Kirkpatrick, C. I. F. (1959). Blood, 14, 535.

O'Gorman, P., Allsopp, K. M., Lehmann, H., and Sukumaran, P. K. (1963). Brit. med. F., 2, 1381

Ramot, B. et al. (1960). Ibid., 2, 1262.

Ranney, H. N. (1958). Nat. Res. Coun. Div. Med. Sci., Publ. No. 557, p. 287.

Schwartz, H., and Spaet, T. H. (1955). Clin. Res. Proc., 3, 51. Sherlock, Sheila (1963). Diseases of the Liver and Biliary System, 3rd

Smith, E. W., and Conley, C. L. (1954). Bull. Fohns Hopk. Hosp., 94,

289. (1958). Nat. Res. Coun. Div. Med. Sci., Publ. No. 557, p. 276.

Vella, F., Beale, D., and Lehmann, H. (1966). Nature (Lond.), 209, 308.

Watson-Williams, E. J. (1962). E. Afr. med. F., 39, 213

Went, L. N., and MacIver, J. E. (1959). Brit. med. f., 2, 138.

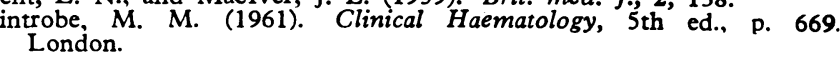

